Bryant University

Bryant Digital Repository

English and Cultural Studies Journal Articles

English and Cultural Studies Faculty

Publications and Research

2010

\title{
Roundtable on Teaching "Work" as an Interdisciplinary First-Year College Seminar
}

\author{
Maura Coughlin \\ Bryant University \\ Bill Dalessio \\ Bryant University \\ Janet E. Dean \\ Bryant University \\ Terri A. Hasseler \\ Bryant University \\ Anthony Martinetti \\ Bryant University
}

See next page for additional authors

Follow this and additional works at: https://digitalcommons.bryant.edu/eng_jou

\section{Recommended Citation}

Coughlin, Maura; Dalessio, Bill; Dean, Janet E.; Hasseler, Terri A.; Martinetti, Anthony; Nielson,

Rex; Okoomian, Janice; and Walden, Elizabeth, "Roundtable on Teaching "Work" as an

Interdisciplinary First-Year College Seminar" (2010). English and Cultural Studies Journal

Articles. Paper 16.

https://digitalcommons.bryant.edu/eng_jou/16

This Article is brought to you for free and open access by the English and Cultural Studies Faculty Publications and Research at Bryant Digital Repository. It has been accepted for inclusion in English and Cultural Studies Journal Articles by an authorized administrator of Bryant Digital Repository. For more information, please contact dcommons@bryant.edu. 


\section{Authors}

Maura Coughlin, Bill Dalessio, Janet E. Dean, Terri A. Hasseler, Anthony Martinetti, Rex Nielson, Janice Okoomian, and Elizabeth Walden 


\title{
Roundtable on teaching "Work" as an interdisci- plinary first-year college seminar
}

\author{
Bryant University \\ Department of English and Cultural Studies
}

Maura Coughlin, Assistant Professor

Bill Dalessio, Adjunct Professor

Janet Dean, Associate Professor

Terri Hasseler, Professor

Anthony Martinetti, Adjunct Professor

Rex Nielson, Adjunct Professor

Janice Okoomian, Adjunct Professor

Elizabeth Walden, Associate Professor

All first-year students at Bryant University in Smithfield, Rhode Island take the First Year Liberal Arts Seminar, an interdisciplinary introduction to liberal arts learning skills, such as critical reading, writing, and visual and textual analysis. Themes and texts for the course change on a yearly basis, giving each first-year cohort a unique, but shared, experience. Each year, we collaboratively design this course around a central theme, such as "conflict," "nature," or "crossing borders." The participating faculty members suggest texts from our own disciplines. Between the fall and spring semesters, we change the text order and change one or two texts. All writing assignments change between semesters to keep the material fresh and to discourage plagiarism.

This past year's theme, "Work," (2009-2010) asked students to interrogate the cultural construction of work from the early industrial revolution to our current economic moment, and to question how the new economy, as it develops, shapes the future conditions of work. Over the course of the year, we considered a number of overarching themes as we attempted to theorize "work" and its place in culture. For instance, we looked at terms we use to describe work (labor, career, job), personal and collective identities associated with work (unions; corporate culture; social and 
economic class positions; race, gender and ethnic identities), representations of work (photography, film, maps, music, literature), and theoretical interpretations of work (alienation from systems of production, gift economies).

Bryant is a private university with about 3400 undergraduates. Founded as a business college in 1863, Bryant's College of Arts and Sciences has been in place since 2004, though degree offerings in liberal arts disciplines, such as English and History, have been in place for over 15 years. More recently, B.A.'s in traditional and new liberal arts disciplines have developed. This particular course, The First Year Liberal Arts Seminar, has been in place for 14 years and has been a central experience for all students, socializing them to the academic community with particular emphasis on critical reading, writing, and thinking.

The eleven faculty who taught their own sections of the seminar come from a range of backgrounds including History, Comparative Literature, English, Writing, ESL, Philosophy, Cultural Studies, American Studies, Women and Gender Studies, and Art History. Our faculty was a mix of tenured, tenure-track, term-appointed, and adjunct faculty (some of whom are graduate students in $\mathrm{PhD}$ programs). We met weekly to share teaching notes and strategies. This faculty seminar, which accompanied the course, is a model for including adjuncts in the pedagogical community. The ability to participate in a vibrant and engaged community of scholars goes far in alleviating the isolation usually attendant upon adjunct faculty. In addition, the fact that adjunct faculty are invited to bring their own interests and expertise to discussions acknowledges their worth as scholars and teachers.

For the theme of "work," we chose a range of texts in political, economic, and social philosophy; sociology; literature; music; and art. In order to provide theoretical models for the discussion of work, we chose texts such as Karl Marx and Frederick Engels, The Economic and Philosophic Manuscripts of 1844 and The Communist Manifesto; Richard Sennett, The Corrosion of Character; and Lewis Hyde, The Gift: Creativity and the Artist in the Modern World. Additionally, non-fictional course materials included Barbara Ehrenreich, Nickel and Dimed: On (Not) Getting by in America; the recent documentary film Manufactured Landscapes, by Jennifer Baichwal; and Anne Whiston Spirn's, Daring to Look: Dorothea Lange's Photographs and Reports from the Field. They were complemented by the recent novel, Last Night at the Lobster by Stewart O'Nan; Charlie Chaplin's classic Modern Times; and works of short fiction and nonfiction in the critical anthology edited by Cecelia Tichi that features Rebecca Harding Davis's novella Life in the Iron Mills. The musical collection Smithsonian Folkways: Class Labor Songs ended the fall semester with yet another mode of representing labor and offering strategies of resistance for the embattled worker.

The following roundtable discussion of our pedagogical strategies for the interdisciplinary teaching of "millenials" (most of whom come to Bryant to pursue degrees in business), was held among the seminar faculty via email in January 2010, as we looked back on the fall semester of the seminar and looked forward to teaching it in a slightly different configuration in the spring.

\section{The Topic of "Work"}

Terri: Work really seemed to be a very relevant topic. With the market crash and 
the incredible impact it had on the students and their families, it was time to look at this culture of capitalism and the type of work ethic it inspires.

Elizabeth: I also saw the moment as an opportunity. It was hard to get students to think critically about social and economic issues when a lot of money was being made in the sorts of fields that they hope to work. While this is a time of crisis, it is also a time of opportunity for learning and reflection. The topic of work is a good one for introducing students to college level education because it speaks to a central feature of human life. Most students today view their education primarily in terms of professional training. But what does that mean in an era of great precarity and economic uncertainty? By thematizing work, by rendering it complex, we bring students back into the traditional liberal arts education's goal of providing a formation, a "Bildung." They begin to see work not simply in terms of making a living, but in terms of creating a way of living that is sustainable for them personally and for society at large.

Rex: I agree, by asking our students to apply liberal arts critical thinking skills to the theme of work, we are likewise helping our students to understand the relevance of the liberal arts to their lives outside the classroom.

Terri: Work permeates so many aspects of Bryant students' lives; many of them do work, but even more so, many of them are very career-oriented. The school's reputation as a business college, which has more recently expanded degree offerings in liberal arts, attracts students who, according to the research, are more careeroriented. College is about professional preparation. With this in mind, making "work" a topic of investigation allows us to dismantle some of their expectations about what work is and will be, and what purposes higher education serves.

Elizabeth: I agree with Terri and would add that in dismantling their expectations we give them a chance to broaden their horizons. While it may be frightening for the students to consider that they are likely to have many more jobs over their careers than their parents, such a consideration can bring them closer to their core values and interests and help develop an attitude toward work that will serve them well in the future.

Terri: I found that students really liked the topic and felt it was immediately relevant to their lives. A myth most students really had a hard time letting go of, however, was the idea that hard work guarantees success, a tenet of their version of the Protestant Work Ethic. Though they might, at one point, recognize that someone might work really hard, like Hugh Wolfe in Rebecca Davis's Life in the Iron Mills, and though they might recognize that poverty may be inescapable, like the experiences of the workers in Barbara Ehrenreich's Nickel and Dimed, they have a hard time translating that to their experiences - that their hard work may not reward them in the ways they expect. So when we read Richard Sennett's The Corrosion of Character, they could not quite imagine themselves in the same position as the IBM workers who were laid off. However, with the market crash, I think this generation is probably starting to be more aware of the instability of the cherished belief that hard work equals success.

Elizabeth: Several of my students have really struggled with all the evidence that Marx may be correct when he insists that capitalism requires poverty. They want to believe that all hard work is rewarded, that there is a real meritocracy at 
work in the global economy. My hope is that our readings encouraged the students to enter sympathetically into the experiences of those that they would often assume are the deserving poor. I think that Charlie Chaplin's Modern Times worked particularly well to that end.

Janet: Many of my students began the class with an abiding faith in human progress, a sense that things are always getting better for the worker. They saw the experiences of Marx's factory worker, Davis's mill workers, Chaplin's Tramp, and Lange's migrants as a sad part of our collective past, but they were quick to point out that things like labor laws and OSHA have vastly improved the worker's lot. The materials that examined contemporary work experiences - by Sennett, Ehrenreich, Hyde, and O'Nan — complicated this idea. Sennett's occasional nostalgia for the strong social bonds and stability of the "old economy" especially challenged students' notions about the inevitability of progress. I found moving back and forth across time in our syllabus to be incredibly productive for encouraging our students to think critically about their own historical moment.

Tony: Several of the students claimed to be social Darwinists; however, it became apparent by the time we reached Life in the Iron Mills, if not before, that they held an innate sense of fairness. For example, students constantly qualified their stance toward Kirby: His only responsibility was to pay his workers on Saturday night, but the pay should be enough to allow the workers and their families a good place to live and to have decent food. The working conditions should be safe, and the workers should have time to rest and recuperate. And Kirby's company should make sure he isn't damaging the environment. And so on. I couldn't help thinking that they would be appalled to see their views as much closer to Europe's social capitalism than social Darwinism.

Elizabeth: I think that the transition to college-level thinking is to a great degree one which encourages an understanding not just of discrete facts, but of systems. Marx is great for getting students to see work, labor for Marx, as part of a larger system without which it is incomprehensible. This is a simple but critical point for understanding the global world in which we live. The students don't necessarily want to see their own hopes for a good job and a certain level of material wealth as inextricably linked to impoverished factory workers in far-flung corners of the globe, or to consider the relationship between their level of consumption and the destruction of the environment. Such insights produce real dissonance and often initially resistance, but discomfort is the beginning of insight and hopefully the first step in taking responsibility for a community larger than the self or the family.

Janice: Many of our students believe that competition is the most fundamental, instinctive drive among human beings. They accept unproblematically the social Darwinist dogma that the fittest survive in the social world. They also think competition is essentially beneficial, both because it motivates people to achieve and because it fits with the received wisdom that the social world progresses in a linear fashion towards perfection and improvement. Lewis Hyde's book, The Gift, really challenged these notions and demonstrated that gift economies are valid alternatives to market (competitive) economies. And we found evidence in other texts (Ehrenreich, O'Nan, Chaplin) that people act on other drives-love, compassion, cooperation, loyalty. 


\section{Theories and Methodologies}

Terri: I was actually quite surprised at how receptive they were to Marx, to the point where I think that there were really some students who embraced some of the values of Communism and Socialism. We started the course at the height of the whole Obama Socialism scare. I thought, for certain, that I would have some educational, right-wing, conspiracy group pounding on our door. I waited to see the headline on FOX news that Bryant faculty indoctrinates entire first-year class with Marx. That may still happen, but I was happily pleased by the disinterested and objective way they approached what has been such a favored American boogeyman.

Elizabeth: Yes, like Terri, I found the students to be sympathetic to Marx, but also I think it was often easier for them to believe that this early humanistic Marx of the Manuscripts was just a starry eyed softy. I found that they were much less sympathetic to Lewis Hyde in The Gift. Marx confirms their idea that labor is something sold in a market. The idea that they should view their labor as a gift seemed the more radical suggestion.

Maura: At times, it seemed as if the students did not want to accept other theoretical models (than Marx) for dealing with the concept of work, so that they tried to fit Richard Sennett's late $20^{\text {th }}$-century concept of the "corrosion of character," which really works best for the white collar, technologically savvy worker, into Marx's concept of the manual laborer's alienation from the product of their labor.

Bill: While my students were receptive to Marx's theory of alienation (perhaps because of their own experiences at summer or part-time jobs), they did not respond well to the Manifesto. While they recognized and understood the problems with capitalism (throughout the course), most did not want to embrace any alternatives to it. And I also remember having a brief discussion about the Obama Socialism scare and health care; as someone without health insurance, I had to struggle to remain impartial and neutral as some of my students expressed their points of view!

Tony: Having lived on an Israeli kibbutz for a couple of years-a thousand years ago-I thought I'd take a chance and use the kibbutz way of life to illustrate many of Marx's ideas. I, too, was pleasantly surprised by how receptive the students were to early Marx writings and to alternative, non-capitalist living. We were able to discuss the advantages and disadvantages of kibbutz life in a balanced way, and we also looked at the New Llano colony in Louisiana as a somewhat successful (existing for 25 years) socialist experiment in the United States.

Janet: It was interesting to see students begin to recognize and think about their own class positions in relation to work. Most of them work summer or part-time jobs alongside older adults who do the same work - waitressing, cleaning houses, landscaping - their entire lives. In this regard they share with Barbara Ehrenreich the privilege of being able to "visit" the working class life without having to stay there. We talked a lot about that privilege: where it comes from, who deserves it, how it relates to social and political power.

Bill: I also found that the course content really lent itself to good discussions regarding our students' different socio-economic backgrounds. While most of my students came from middle-class or upper middle-class families, some came from working-class backgrounds and therefore brought a different (perhaps a more 
realistic and less romanticized) perspective regarding work into our discussions of texts like Nickel and Dimed or Last Night at the Lobster. We also touched on issues of gender identity in our discussions. We looked at how the male bosses (especially in Nickel and Dimed and Last Night at the Lobster) treated their female employees, similarly and differently. We also discussed the important but often overlooked roles that women, such as the Gamin from Modern Times and the character Deborah from Life in the Iron Mills, played as they supported the male workers both at home and at their jobs.

Janice: The Gift prompted a very insightful discussion about art and work. Students tend to think "artists" are a separate category of people (unlike business people or other professionals). We talked about how the practice of making art in Western cultures tends to be reserved for the "professionals" but that in many other cultural contexts people make art all the time. Students talked about their own experiences playing musical instruments and why they make art-not always for financial or professional gain.

\section{Pedagogical Approaches}

Terri: I think more than any course, the first year liberal arts seminar prepares students for the university learning community - seminar-based, discussion-oriented. Students are responsible for coming prepared and carrying the conversation. They are also asked to do some pretty sophisticated writing, often comparing very disparate thinkers and texts such as Marx's manifesto, Charlie Chaplin's film, and Ehrenreich's journalistic study.

Maura: The seminar enrollment caps at 25 students so we get to know our first-year students quite well. We work closely with them in writing conferences and in the classroom to help them develop skills of oral and written expression and critical thinking.

Terri: The seminar is absolutely critical to the experience. Students learn that the work of the university is to engage in intellectual debate, and that happens best in a seminar format.

Elizabeth: I used the concept of alienation that they were familiar with from Marx to discuss their own attitudes toward their education and course work. The seminar format gives everyone a stake in building the course together. It is a model of effective collaborative work.

Janice: Given that our class sizes are actually 25 , and that some of our students are not strong conceptual thinkers, it can be hard to get people to talk in class. I ask one student to read a brief passage and then I pose a question to that student about it. Others are welcome to join in, and they usually do. This close reading method also has the advantage of making sure students are staying grounded in the texts. On occasion, we have held discussions via live chat, and the students love this approach. They feel more at ease and less shy about contributing to the discussion. From my perspective, the online discussions tend to lack depth, but they are a great ice-breaker for this population.

Janet: The course theme made it possible for the class to develop self-awareness about the work of learning. For instance, I had students collaborate to answer questions raised by texts, but before reporting their findings to the class, I asked them to 
comment on their experience of working in teams. Was it a productive collaboration, or was it superficial, as Sennett suggests of the teamwork of "flexible capitalism"? Was it more or less useful than independent work? Why? Working individually with students in conferences, I encouraged similar kinds of reflection about what reading and writing practices worked best. This kind of reflection is particularly important for first-year students, who are sometimes too passive in their approach to difficult material. They began to recognize that learning doesn't just happen; it's work, and it benefits from careful thinking about methodologies and practices.

Maura: On the very first day, I asked the students to talk about the most rewarding and most difficult jobs they had ever held. Over the course of the semester we repeatedly returned to this discussion. Their responses to these questions gave me a very important window into their range of backgrounds and degrees of socioeconomic advantage.

Elizabeth: I found it effective to have students consider what sort of expectations people have of their working lives beyond financial compensation. Our students, quite understandably, are concerned with getting a foothold in the economy and getting jobs that will allow them to maintain or increase their standard of living, but they really came to realize that their expectations should be and are higher than that-that work is often where we express and explore who we are in relation to others and where we build and take responsibility for community.

Terri: The "work of learning" is a great focus and much of the work students do is writing-based. My favorite writing activity asked students to look at cultural expectations related to social class. I asked them why we expect the middle class to be responsible workers and the working class to be humble workers. It was a useful activity to get them to think about why they were only comfortable with those poor who were obsequious, grateful, and hard-working. It helped them to think about why they had a hard time forgiving Hugh (in Life in the Iron Mills) for stealing. In class discussion, they argued that if he were on the point of death, then it was okay to steal, but since he had a sufficient amount of food to keep him alive (barely), stealing was not acceptable. They also wanted to reject the idea that Hugh may be stealing so that he could have a better life to pursue his art; that would not be humble, that would be demanding and taking to make one's life better, and they felt that was completely unacceptable. Yet, they themselves, would not want that life, but could offer no alternative, except that he should work harder. Writing about these ideas helped them to see the problems in their arguments. The intensive and very sophisticated forms of writing required in the course stretch them in really profound ways.

Bill: For me, written assignments that were a mixture of textual analysis and self-reflection worked the best; I sometimes asked students to use their own experiences to evaluate a theory or idea from a text, or to compare and contrast their own experiences and observations to those in the text. I also found that sequential assignments were helpful to students; their two long papers often built on their shorter response papers, class presentations, or class discussions.

Janet: I agree with Bill that, perhaps more than any other topic we've had for the course, this one really lends itself to productive self-reflection. This was a 
topic that students could relate to their own experience of having part-time jobs, doing chores, volunteering, or studying. Bringing their own histories to bear on the readings helped students gain confidence in evaluating complex theories and positions. In some respects, everyone is an expert on work.

Janice: The seminar writing assignments, like the reading and discussion assignments, are intended to help students begin to enter into college-level discourse. I find many of my students begin the term trying to scope out what they think their teacher "wants to hear," and some of them take up positions in their papers which they think I adhere to (for instance, capitalism is evil) in an attempt to curry my favor. Needless to say, this strategy usually produces terrible papers, and it gives me an opportunity to help them realize that they will be most convincing as writers when they are sincere. Likewise, our paper topics are designed to help students move beyond binary argumentation and false polarizations, and introduce them to complexity and nuance in argument.

Tony: Early on in the semester, I found that the students, while having sympathy for the workers, felt removed from them mainly because of socio-economic differences. As a short writing assignment, I asked the students to write a monologue in the voice of one of Ehrenreich's workers. The monologue was to center on a time soon after the worker had read or heard about Marx's ideas found in the manuscripts and in the manifesto. The student needed to consider the ways these ideas might have influenced the character.

\section{Interdisciplinarity in First Year Teaching}

Elizabeth: I think that the interdisciplinary nature of the course is critical to its success as an introduction to college learning. The course ranges across materials and approaches and encourages supple intellectual synthesis of what the student encounters. It creates a model for their education in general, which I hope allows them to draw connections among all their courses and to gain more from the education than the sum of its parts.

Maura: As an art historian, I have input on choices of texts for the seminar that discuss various forms of visual culture such as painting, photography, and film. This year's theme has provided great opportunities to not only discuss visual representations of work, but to also consider the work of the artist and the social and ethical implications of representing workers. In the case of Dorothea Lange working for the WPA in the 1930s, this became a very productive discussion of the common cultural, rather than monetary, value of a work of art. I use a lot of visual images and examples from my own field in the course of teaching my sections of the seminar. For instance, while we were reading Marx, I showed the students a few minutes of John Berger's classic program Ways of Seeing and then we had a discussion of how his analysis of works of art is informed by a Marxist perspective.

Janice: My degree is in American Studies, which is itself an interdisciplinary field, so I am very comfortable working with texts across disciplines, but I sometimes lack the depth in particular subject areas that others have. For this reason, the faculty meetings and presentations are especially helpful.

Rex: Like Janice, I found the faculty meetings in which we strategized how to 
present the various texts to our students essential. My degree is in Portuguese and Brazilian Studies and I frequently tried to help my students consider the global implications of work and labor. For example, when we taught Anne Whiston Spirn's book Daring to Look about Dorothea Lange, I brought into class a series of images by the Brazilian photographer Sebastião Salgado, who is also a noted photographer of labor. Pairing Lange and Salgado's images prompted an interesting comparative discussion about our national imagery of work in contrast to the kinds of images that are prevalent in other cultures.

Maura: One day when we were discussing Davis's Life in the Iron Mills, I had the students come to class prepared to critically analyze a range of websites that promote former mills in Eastern Massachusetts and Rhode Island. They had to bring to class not only a critique of the ways that the past was presented but they had to also suggest visual interventions in the present exhibitions that might better animate the exhibition.

Janice: And on a similar note, for the first time this year we included a collection of music as one of the course texts-the Smithsonian Labor songs. It was particularly interesting to talk about how folk music builds communities, and how the formal differences between a performance form like music and a visual form like photography engage listeners/viewers in different ways.

Maura: This spring we will add Jennifer Baichwal's documentary Manufactured Landscapes to the syllabus. This recent film, about Canadian photographer, Edward Burtynsky, encourages the students to think more globally about their own patterns of consumption. Although we talk about Adam Smith's analysis of the mind-numbing effects of repetitive factory work in reference to Nickel and Dimed, Life in the Iron Mills and Modern Times, Baichwal and Burtynsky's images of Chinese factories and e-waste recycling in China and container ship demolition in Bangladesh bring this dialogue up to date in the context of globalized production.

Janice: I actually think that this year's topic and materials has been more difficult to address in terms of gender, not because we lack evidence of women's experience, but because we don't have materials to adequately theorize gender and work. More generally, it can be hard to achieve sufficient depth of analysis on all topics with first-year students.

Maura: I agree with Janice. Most of my students don't have much understanding that the historical construction of the suburban housewife as someone who does not "work," for example, begins as late as the mid- $20^{\text {th }}$ century.

Terri: I think that the biggest dilemma we face when pulling texts together is the issue of "coverage." Although "class" and "gender" are all over the course, though hard to pull out as discrete subjects, "race" was more hidden.

Elizabeth: Class is such an important category to work with, because it is antithetical in many ways to American identity: the American dream seems to promise that one can begin anywhere and achieve anything. But I agree that, at this level of study, it was hard to both introduce and discuss class issues and address gender, race, and globalism in sufficient depth at the same time. Part of this is due to the topic and part undoubtedly to the choice of texts. I don't think it is the interdisciplinarity of the course that is the problem, but the very broadness of the theme. Paradoxically, I think the course ended up to be both too Marxist and not 
Marxist enough. Class as an identity category dominated much of the course, but we didn't enter into class deeply enough (or at least I wasn't able to) to bring in all the fine critiques of its limitations as a social category that have been launched by Marxist feminism, race theory, and post-colonialism. I think that our inclusion of Manufactured Landscapes will help with some of these issues in the Spring term, but I'd like to keep the topic and refine it further for future years.

Tony: During the first week, a student had come across the truncated "religion is the opium of the people" quote and wanted to know more about it. Our class discussion allowed for a more involved understanding of Marx's attitude toward religion and opened the door for connections between workers and religion in Nickel and Dimed, Modern Times, (IBM workers in) Corrosion of Character, Life in the Iron Mills, and some of the labor songs.

Terri: Religion was also a topic that emerged from class discussion in my classes, and I was surprised by how engaged students were with it. It was most interesting when we talked about the idea of an afterlife, and how some religious systems support the capitalist system by preaching that one should just "put up" with the problems of this world because one's reward would come in heaven. This theme recurred in the labor songs, with one song, in particular, passionately arguing that this is a lie. Many students were able to connect this back to general conversations on Marx’s "opium” quote.

\section{Works Cited}

Davis, Rebecca Harding. Life in the Iron Mills. Ed. Cecelia Tichi. Boston: Bedford Books, 1998.

Ehrenreich, Barbara. Nickel and Dimed on (Not) Getting By in America. New York: Holt, 2008.

Hyde, Lewis. The Gift: Creativity and the Artist in the Modern World. 1983. New York: Vintage, 2007.

Manufactured Landscapes. Dir. Jennifer Baichwal. National Film Board of Canada, 2006. DVD. Zeitgeist Films, 2007.

Marx, Karl, and Frederick Engels. Economic and Philosophic Manuscripts of 1844 and the Communist Manifesto. New York: Prometheus Books, 1988.

Modern Times. Dir. Charlie Chaplin. United Artists, 1936.

O’Nan, Stewart. Last Night at the Lobster: a Novel. New York: Viking, 2007.

Sennett, Richard. The Corrosion of Character: The Personal Consequences of Work in the New Capitalism. New York: Norton, 2000.

Smithsonian Folkways: Class Labor Songs. Smithsonian Folkways Recordings, 2006. CD.

Spirn, Anne Whiston. Daring to Look: Dorothea Lange's Photographs and Reports from the Field. Chicago: University Of Chicago Press, 2009. 
Reproduced with permission of the copyright owner. Further reproduction prohibited without permission. 